\title{
THE NAME OF THE LAC INSECTS
}

\author{
By T. D. A. Cockerell. \\ University of Colorado
}

The Monograph of the Tachardiinæ, by Mr. J. C. Chamberlin, recently published in Bulletin of Entomological Research, vol. XIV, is certainly a fine example of modern work on Coccidæ. It appears to exhaust the subject so far as the available materials permit, but of course many species remain to be discovered, and there is much to be done on the biology of all. Before it was published, I called the attention of Professor Ferris to the name Laccifer Oken, but he presumably had no access to Oken's work. I am indebted to Mr. C. D. Sherborn for a copy of Oken's account, in Lehrb. Naturg., III (1), 1815, p. 430. He proposes a genus Laccifer, for "Chermes or Coccus lacca." It is stated to be the source of the gum-lac, and to occur by the Ganges on Mimosa cinerea and M.glauca, plants now known as Dichrostachys cinerea (L.) Wight \& Arn. and Leuccena glauca (L.) Benth. The old error of taking the male coccid for the adult female and some hymenopterous parasite for the adult female is repeated, but does not invalidate the name. I agree with Ferris that these peculiar insects deserve to rank as a family, and accordingly the following changes appear to be necessary:

Family Lacciferidæ (Tachardiidæ Fcrris)

Subfamily Lacciferinæ (Tachardiinæ Ckll., pars.)

Laccifer albizzice (Green, as Tachardia)

Laccifer meridionalis (Chamb., as Tachardia)

Laccifer greeni (Chamb., as Tachardia)

Laccifer fici (Green, as Tachardia)

Laccifer ebrachiatus (Chamb., as Tachardia)

Laccifer lacca (Kerr, as Coccus)

Laccifer conchiferatus (Green, as Tachardia)

It may be noted that according to the rules Tachardina lobata is to be credited to Green, as he not only published a full description, but gave the name and mentioned a difference from the 
Philippine T. minuta. Also the combination Tachardina albida should not be credited to me, but to MacGillivray; I used the name Tachardina only in a subgeneric sense. Mr. Chamberlin indicates subgenera and then immediately uses the names in a generic sense, which is illogical; but it may be anticipated that the latter treatment will eventually prevail. 

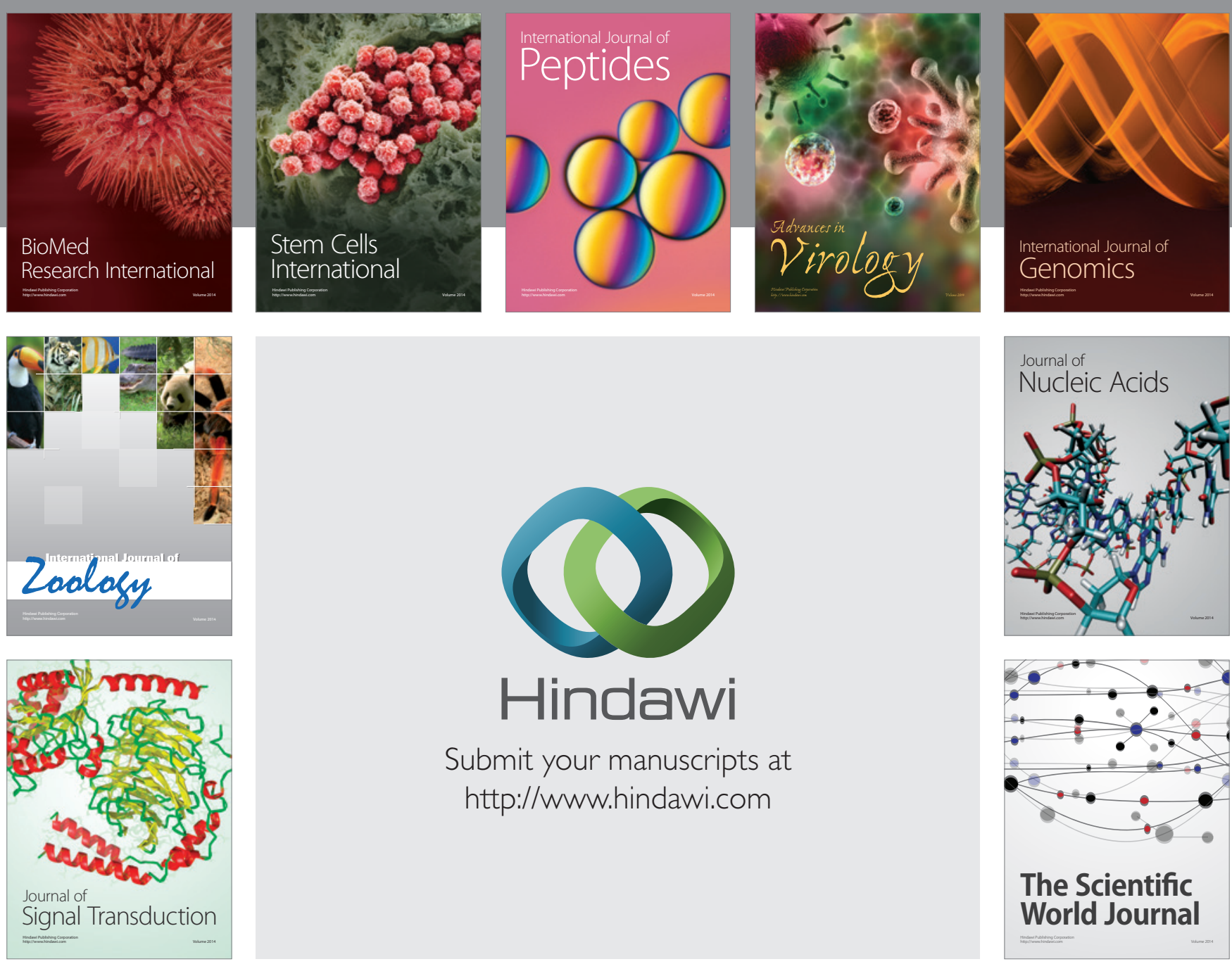

Submit your manuscripts at

http://www.hindawi.com
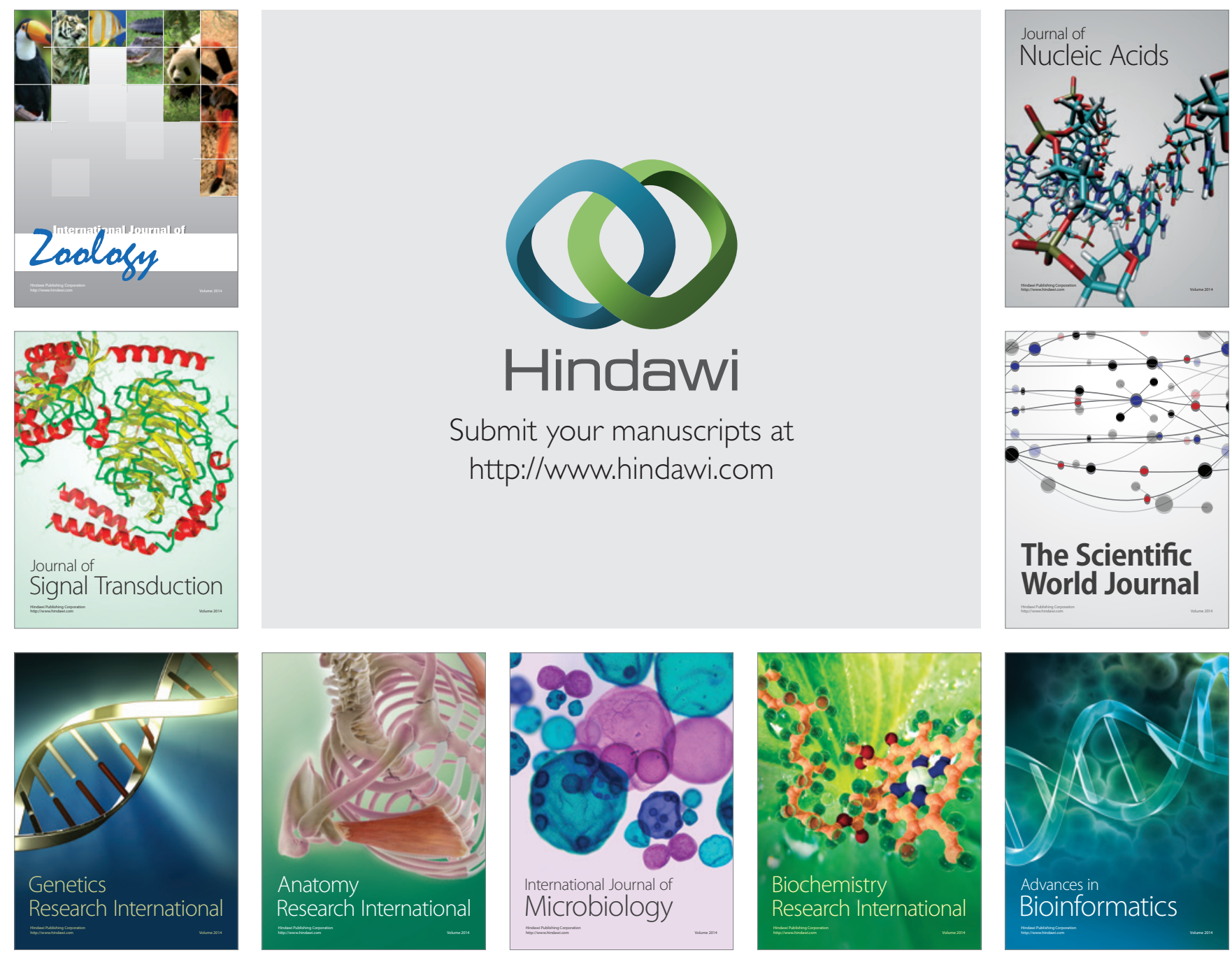

The Scientific World Journal
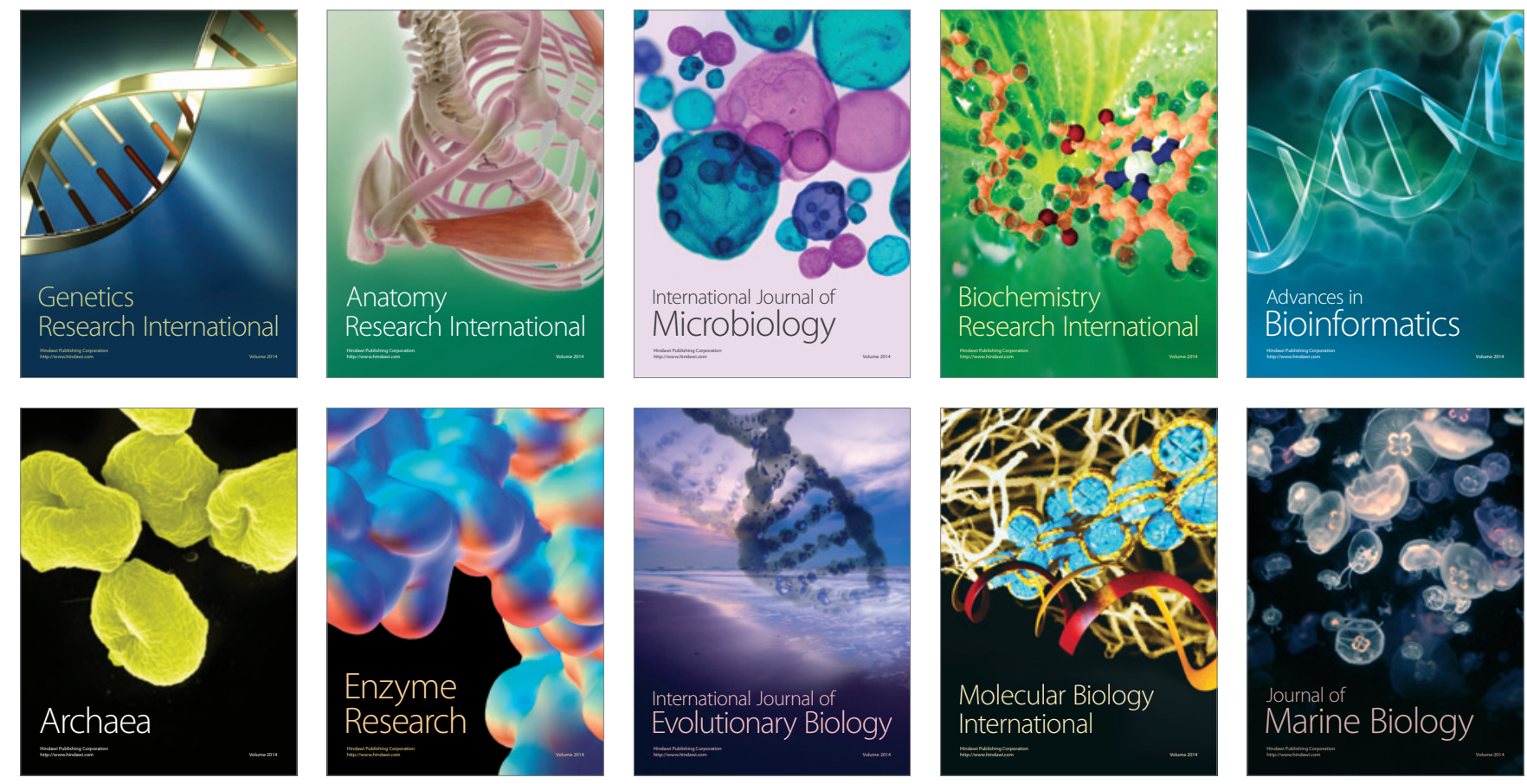